\title{
The Valence State of Technetium-99 in its Complexes with Bleomycin, 1-Hydroxy-ethylidene-1,1-diphosphonate and Human Serum Albumin
}

\author{
J. KORTELAND, B. G. DEKKER and C. L. DE LIGNY \\ Laboratory for Analytical Chemistry, University of Utrecht, Croesestraat 77A, 3522 AD Utrecht, \\ The Netherlands
}

(Received 13 October 1978)

\begin{abstract}
The valence state of technetium- 99 in its complexes with bleomycin, 1-hydroxy-ethylidene-1,1diphosphonate and human serum albumin was determined by titration of ${ }^{99} \mathrm{TcO}_{4}^{-}$with $\mathrm{Sn}(\mathrm{II})$ in the presence of these complexing agents. Both direct titration, and addition of an excess of Sn(II) and back-titration with iodine was employed.
\end{abstract}

\section{Introduction}

MANY ${ }^{99 m} \mathrm{Tc}$ radiopharmaceuticals are prepared via the reduction of pertechnetate by stannous chloride in the presence of the chelating agent. From the stoichiometry of the reduction reaction it is possible to elucidate the valence state of technetium in the chelate. However, meaningful analyses can be carried out only with millimolar amounts of technetium and not with the nanomolar quantities of ${ }^{99 \mathrm{~m}} \mathrm{Tc}$ which are employed in medical practice. Therefore carrier technetium $\left({ }^{99} \mathrm{Tc}\right)$ was used in the experiments reported here. The applicability of the results to the nanomolar concentration level is not beyond doubt, ${ }^{(1,2)}$ but at least they will contribute to the knowledge of the chemistry of technetium- $99 m$ radiopharmaceuticals.

The oxidation state of technetium has already been investigated in a number of radiopharmaceuticals; among these are ${ }^{99} \mathrm{Tc}$-gluconate and ${ }^{99} \mathrm{Tc}$-1-hydroxyethylidene-1,1-diphosphonate $\left({ }^{99} \mathrm{Tc}-\mathrm{EHDP}\right),{ }^{\left({ }^{3)}\right.}{ }^{99} \mathrm{Tc}-$ diethylenetriamine-pentacetic acid, ${ }^{(1)}$ and ${ }^{99} \mathrm{Tc}-N$ (2,6 - dimethylphenylcarbamoylmethyl) - iminodiacetic acid $^{(4)}$. This paper describes the determination of the valence state of ${ }^{99} \mathrm{Tc}$ in its complexes with bleomycin (Bleo) and human serum albumin (HSA). As a check, the valence state of ${ }^{99} \mathrm{~T} \mathrm{c}$ in the EHDP complex was also determined.

Two titration methods with potentiometric end point detection were employed, viz. direct titration of ${ }^{99} \mathrm{TcO}_{4}^{-}$with $\mathrm{SnCl}_{2}$ and iodimetric titration of unreacted $\mathrm{SnCl}_{2}$ added in excess to pertechnetate.

It is generally known that the yield of technetium incorporated into a radiopharmaceutical is influenced by the order of combining the reagents, the concentration of the reagents and the $\mathrm{pH}^{(2,5-7)}$ Therefore, after the reduction, the labeling percentage was determined using thin-layer and paper chromatography.

\section{Experimental}

\section{Chemicals}

${ }^{99} \mathrm{Tc}$-generator and $\mathrm{NH}_{4}{ }^{99} \mathrm{TCO}_{4}$ : New England Nuclear. Bleomycin: Lundbeck, $67.4 \% \mathrm{~A}_{2}, 28.8 \% \mathrm{~B}_{2}$ and $3.8 \% A_{1}$. EHDP: synthesized according to CAsTronovo. ${ }^{(8)}$ Human serum albumin: Red Cross Laboratory, Amsterdam. Thin-layer plates: Merck, Kieselgel 60F254 Fertigplatten. Chromatography paper: Whatman No. 1. All other chemicals, from commercial sources, were of the highest obtainable purity.

\section{Equipment}

The titrations were performed with an automatic, potentiometric titration system with curve recording. The complete equipment comprised:

(1) A closed titration vessel containing a platinum indicator electrode, a saturated calomel reference electrode and a glass membrane combination electrode. The vessel and the solutions were deaerated with nitrogen.

(2) An automatic burette, Autoburette ABU11 (Radiometer, Copenhagen). In order to extend the titration time to about $3 \mathrm{~h}$ the input for remote control of the burette was shortcircuited periodically by means of a multivibrator.

(3) A Servogor RE 511 recorder connected to the output of a Knick Labor-pH-meter for the registration of the titration curve. The $\mathrm{pH}$ was measured with a Metrohm E $350 \mathrm{~B} \mathrm{pH}$ meter.

\section{Procedure}

To prevent oxidation of $\mathrm{Sn}(\mathrm{II})$ all solutions were prepared oxygen-free and stored under nitrogen. A stock solution of $2 \times 10^{-2} \mathrm{M} \mathrm{SnCl}_{2}$ in $\mathrm{HCl}$ was pre- 
pared every two weeks. A $2 \times 10^{-3} \mathrm{M}$ solution was made immediately before use and standardized against an iodine solution $\left(5 \times 10^{-3} \mathrm{M} \mathrm{I}_{2}\right.$ in $10^{-2} \mathrm{M} \mathrm{KI}$ ). The $\mathrm{pH}$ of the diluted $\mathrm{SnCl}_{2}$ solution was adjusted to 2.6 (for Bleo and EHDP) or 1.3 (for HSA).

The direct potentiometric titration of ${ }^{99} \mathrm{TcO}_{4}^{-}$with $\mathrm{SnCl}_{2}$ was performed as follows: first the chelating agent was put into the titration vessel $(15 \mathrm{mg}$ of Bleo or $5 \mathrm{mg}$ of EHDP or $8 \mathrm{ml}$ of $20 \%$ HSA). Next $1 \mathrm{ml}$ of $1.89 \times 10^{-3} \mathrm{M} \mathrm{NH}_{4}{ }^{99} \mathrm{TcO}_{4}$ was added. The $\mathrm{pH}$ was adjusted to the desired value with $\mathrm{HCl}$. The volume was made up to $10 \mathrm{ml}$ by adding a physiological saline solution of the appropriate $\mathrm{pH}$. The titration was started by adding $0.1 \mathrm{ml}$ of $2 \times 10^{-3} \mathrm{M} \mathrm{SnCl}_{2}$; then the mixture was stirred for about $20 \mathrm{~min}$ in order to achieve a constant potential reading. After this interval the titration was continued and at least an additional $100 \mathrm{~min}$ were spent to reach the end point. Titrations of ${ }^{99} \mathrm{TcO}_{4}^{-}$in $\mathrm{HCl}$ solution $(\mathrm{pH}=1.3$ and 2.6) without complexing agent were performed in the same way with variable titration time.

The potentiometric titration of excess $\mathrm{Sn}(\mathrm{II})$ with iodine was performed as follows: first $15 \mathrm{mg}$ of Bleo or $5 \mathrm{mg}$ of EHDP were put into the titration vessel. Next $1 \mathrm{ml}$ of $1.89 \times 10^{-3} \mathrm{M} \mathrm{NH}_{4}{ }^{99} \mathrm{TcO}_{4}$ was added, the $\mathrm{pH}$ was adjusted and $5 \mathrm{ml}$ of $2 \times 10^{-3} \mathrm{M} \mathrm{SnCl}_{2}$ was added. The reaction volume was made up to $10 \mathrm{ml}$ with physiological saline of the appropriate $\mathrm{pH}$. After the reaction mixture was stirred for $15 \mathrm{~min}$ the unreacted $\mathrm{Sn}(\mathrm{II})$ was titrated with iodine solution $\left(5 \times 10^{-3} \mathrm{M} \mathrm{I}_{2}\right.$ in $\left.10^{-2} \mathrm{M} \mathrm{KI}\right)$. Also a number of titrations in $\mathrm{HCl}$ solution without complexing agent was performed.

The labeling percentage was determined using both thin-layer and paper chromatography. The procedure was as follows: the titrations were carried out as described above with the difference that an amount of ${ }^{99} \mathrm{TcO}_{4}^{-}$was added as a tracer for the chromatographic determinations. After the titration an aliquot of the solution was spotted on a thin-layer plate and/ or paper strip. For Tc-Bleo a thin-layer chromatogram on silica gel was made, as described by BARTELS et $a l^{(6)}$ The labeling efficiency for Tc-EHDP and TcHSA was evaluated by means of a two-strip chromatographic procedure. ${ }^{(9)}$ The activity distribution of ${ }^{99} \mathrm{~m}$ Tc on the chromatograms was determined using a single channel analyser equipped with a well-type $\mathrm{NaI}$ crystal. In the case of Tc-HSA two paper chromatograms were made, using acetone and physiological saline as the developing solvents, respectively. In acetone the reduced unbound technetium, $\mathrm{Tc}_{\mathrm{r}, \mathrm{u}}$, and Tc-HSA remain at the origin, whereas $\mathrm{TcO}_{4}^{-}$migrates close to the solvent front. In saline $\mathrm{Tc}_{\mathrm{r}, \mathrm{u}}$ remains at the origin, whereas $\mathrm{TcO}_{4}^{-}$and Tc-HSA migrate rapidly $\left(R_{f}=0.65-0.80\right.$ and $R_{f}=0.85-0.95$, respectively). ${ }^{(10)}$

As the iodine reagent might oxidize reduced technetium species, ${ }^{(1,2)}$ labeling percentages were determined before and after the iodimetric titration. However, no significant difference was found.

\section{Results and Discussion}

Figure 1 shows the number of equivalents transferred to $1 \mathrm{~mol}$ of $\mathrm{TcO}_{4}^{-}, n$, as a function of the titration time in the direct titration of pertechnetate in $\mathrm{HCl}$ solutions $(\mathrm{pH}=2.6$ ). Apparently $2 \mathrm{~h}$ should be spent on a titration to be sure that the reduction is complete. For this reason an automatic titration equipment was used, and at least $2 \mathrm{~h}$ were spent on the direct titrations in the presence of Bleo, EHDP or HSA.

Figure 2 shows a typical titration curve for reduction in the presence of Bleo; titration in the presence of EHDP gave a similar curve. In contrast with these results two end points were registrated for reduction in the presence of HSA, corresponding with $\mathrm{Tc}(\mathrm{V})$ HSA and TC(IV)-HSA (in the example of Fig. 2 the labeling percentage was $92 \%$; see also Table 1 ).

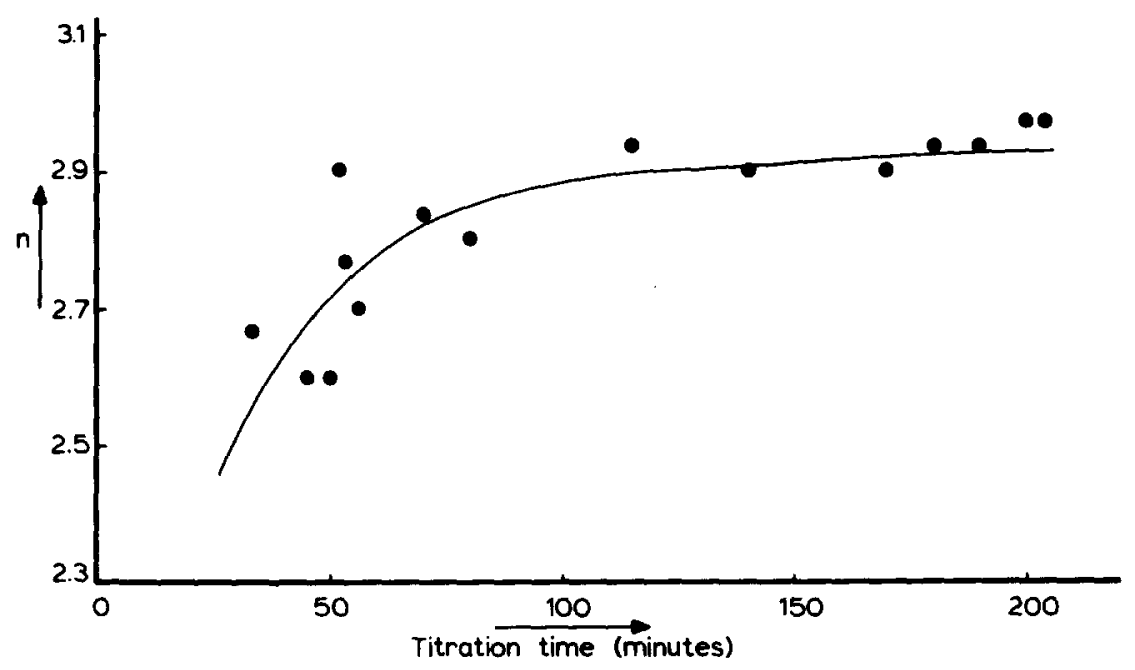

FIG. 1. Number of equivalents $(n)$ transferred to $1 \mathrm{~mol} \mathrm{of}^{99} \mathrm{TcO}_{4}{ }^{-}$as a function of the titration time. 


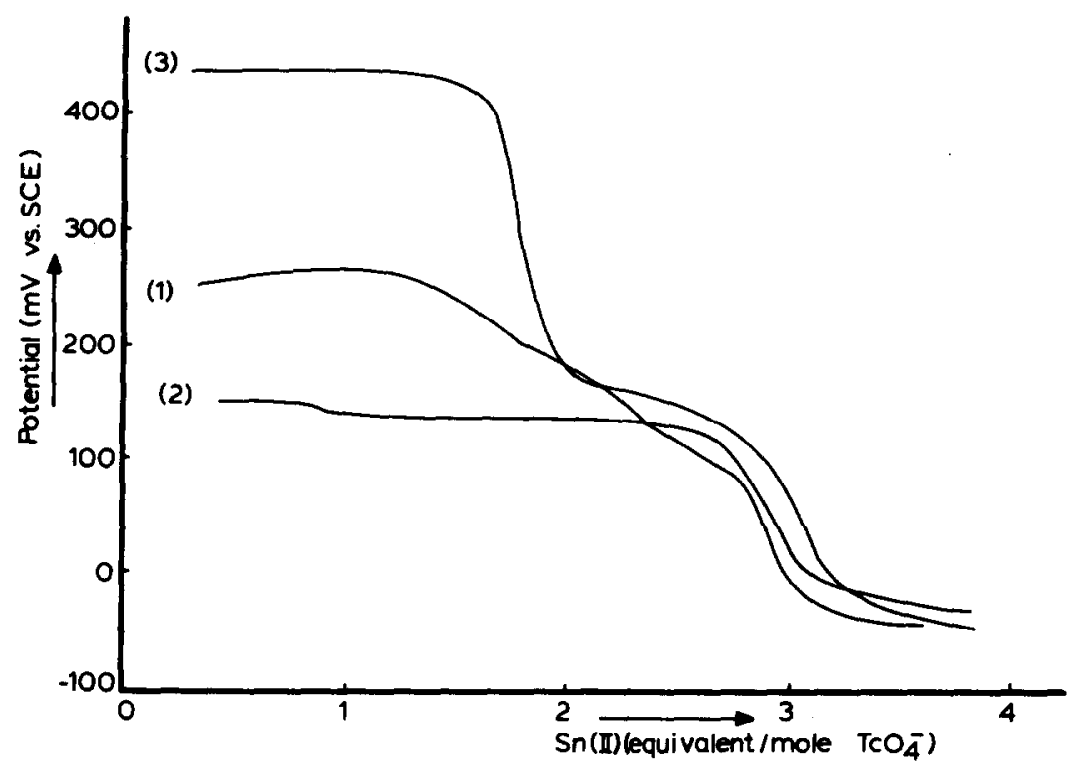

FIG. 2. Direct potentiometric titration of ${ }^{99} \mathrm{TcO}_{4}^{-}$with stannous chloride in the presence of: (1) $\mathrm{HCl}$, $\mathrm{pH}=2.6$; (2) Bleo, $\mathrm{pH}=2.6$; (3) $\mathrm{HSA}, \mathrm{pH}=1.3$.

Apparently a Tc(V)-HSA complex is formed first, and this is further reduced to a Tc(IV)-HSA complex when more $\mathrm{Sn}$ (II) is added. It follows that in ${ }^{99} \mathrm{~m}$ Tc-HSA chelates, prepared by reduction of ${ }^{99} \mathrm{mcO}_{4}^{-}$with (an excess of) $\mathrm{Sn}(\mathrm{II}),{ }^{99 \mathrm{~m}} \mathrm{Tc}$ is in the (IV) state.

Table 1 shows the results of the direct and the iodimetric titrations and the observed labeling percentages of the investigated radiopharmaceuticals. (As iodine reacts with both $\mathrm{Sn}$ (II) and HSA a titration with iodine in the presence of HSA was meaningless). In $\mathrm{HCl}$ solutions both at $\mathrm{pH}=1.3$ and 2.6 the value of $n$ is about 3 ; i.e. ${ }^{99} \mathrm{TcO}_{4}^{-}$is reduced to the $\mathrm{Tc}$ (IV) state. Raising the $\mathrm{pH}$ above 3 gives a brown-black precipitate of $\mathrm{TcO}_{2} \cdot 2 \mathrm{H}_{2} \mathrm{O}$ as is reported by other authors. $^{(11,12)}$ This result is in agreement with data given by SteigmaN et al. ${ }^{(1)}$ and HAMBRIGHT et al. ${ }^{(3)}$ on the reduction of ${ }^{99} \mathrm{TcO}_{4}^{-}$by $\mathrm{SnCl}_{2}$ in $0.1-2 \mathrm{M} \mathrm{HCl}$ and $5 \mathrm{M} \mathrm{HCl}$ respectively, and casts serious doubt on the statement of BRATU et al. ${ }^{(13)}$ that ${ }^{99} \mathrm{TcO}_{4}^{-}$is reduced to the $\mathrm{Tc}(\mathrm{V})$ state by $\mathrm{SnCl}_{2}$ in $2 \mathrm{M} \mathrm{HCl}$. The cause of this deviating opinion of the last mentioned authors is probably the inappropriate oxidant that they used to back-titrate the excess of $\mathrm{Sn}(\mathrm{II})$, i.e. $\mathrm{Ce}(\mathrm{IV})$. According to RuLfs, ${ }^{14}{ }^{4} \mathrm{Ce}(\mathrm{IV})$ oxidizes lower valence states of $T c$ to the $T c(V)$ state simultaneously with the oxidation of the excess of $\mathrm{Sn}$ (II). From Table 1 it appears that $\mathrm{Tc}(\mathrm{IV})$ is also found after reduction in the presence of Bleo or EHDP. The TCIV) oxidation state has also been reported by HAMBRIGHT et al. ${ }^{(3)}$ for the EHDP system at $\mathrm{pH}=5.5$.

Previously we investigated the influence of the $\mathrm{pH}$ and of the $\mathrm{Sn}(\mathrm{II})$ and ligand concentrations on the efficiency of the labeling of $\mathrm{HSA}^{(5)} \mathrm{Bleo}^{(6)}$ or EHDP ${ }^{(7)}$ with ${ }^{99} \mathrm{mc}$, and established the optimum labeling conditions for these radiopharmaceuticals. It is interesting to investigate the applicability of these results to the higher concentration level of carrier ${ }^{99} \mathrm{Tc}$. The estimated percentages, derived from the

TABLE 1. Results of titrations of pertechnetate in the presence of chelating agents and in $\mathrm{HCl}$ medium, and labeling percentages of the chelating agents

\begin{tabular}{|c|c|c|c|c|c|c|}
\hline \multirow[b]{2}{*}{$\begin{array}{l}\text { Chelating } \\
\text { agent }\end{array}$} & \multicolumn{3}{|c|}{ Direct titration with $\operatorname{Sn}(\mathrm{II})$} & \multicolumn{3}{|c|}{ Iodimetric titrations } \\
\hline & $\mathrm{pH}$ & $n$ & $\begin{array}{l}\text { Labeling } \\
\text { percentage }\end{array}$ & $\mathrm{pH}$ & $n$ & $\begin{array}{c}\text { Labeling } \\
\text { percentage }\end{array}$ \\
\hline Bleo & 2.6 & $2.9 \pm 0.1$ & $65 \pm 2$ & 3.1 & $2.7 \pm 0.2$ & $71 \pm 3$ \\
\hline EHDP & 2.6 & $3.2 \pm 0.1$ & $73 \pm 3$ & 3.0 & $3.0 \pm 0.2$ & $92 \pm 3$ \\
\hline \multirow[t]{2}{*}{ HSA } & 1.3 & $1.8 \pm 0.1$ & $86 \pm 4$ & - & - & - \\
\hline & - & $3.0 \pm 0.2^{a}$ & $=$ & - & - & - \\
\hline $\mathrm{HCl}$ medium & 1.3 & $2.9 \pm 0.2$ & - & 1.3 & $2.8 \pm 0.1$ & - \\
\hline $\mathrm{HCl}$ medium & 2.6 & $3.1 \pm 0.2$ & - & 2.6 & $3.2 \pm 0.2$ & - \\
\hline
\end{tabular}

$n=$ number of equivalents transferred to $1 \mathrm{~mol}$ of $\mathrm{TcO}_{4}^{-}$

${ }^{2}$ In the presence of HSA two end points were registered.

On average 4 titrations were performed. 
equations describing the labeling efficiencies with $99 \mathrm{~m} \mathrm{Tc}$ as functions of the investigated variables are: for Bleo $64 \%$ at $\mathrm{pH}=2.6$ and $68 \%$ at $\mathrm{pH}=3.1$, for EHDP $97 \%$ at $\mathrm{pH}=2.6$ and $98 \%$ at $\mathrm{pH}=3.0$, and for HSA $93 \%$ at $\mathrm{pH}=1.3$. The labeling percentages with ${ }^{99} \mathrm{Tc}$ found in the present work (see Table 1) are in good agreement with the estimated values, with the exception of the low value of the labeling percentage of EHDP obtained at $\mathrm{pH}=2.6$.

\section{Conclusions}

$\mathrm{SnCl}_{2}$ reduces ${ }^{99} \mathrm{TcO}_{4}^{-}$to the $\mathrm{Tc}(\mathrm{IV})$ state in a $\mathrm{HCl}$ medium and in the presence of the chelating agent 1-hydroxy-ethylidene-1,1-diphosphonate and bleomycin. In the presence of human serum albumin a $\mathrm{Tc}(\mathrm{V})$ or a Tc(IV)-albumin complex is formed, depending on the amount of reductant.

The labeling percentages of the chelating agents with millimolar amounts of ${ }^{99} \mathrm{Tc}$ are in good agreement with the values predicted on the basis of the results of investigations with nanomolar amounts of ${ }^{99 m}$ Tc.

\section{References}

I. Steigman J., Meinken G. and Richarids P. Int. J. appl. Radiat. Isotopes 26, 601 (1975).

2. Eckelman W. C. and Levenson S. M. Int. J. appl. Radiat. Isotopes 28, 67 (1977).

3. Hambright P., McRae J., Valk P. E., Bearden A. J. and ShiPLeY B. A. J. nucl. Med. 16, 478 (1975).

4. LoberG M. D. and FieldS A. T. Int. J. appl. Radiat. Isotopes 29, 167 (1978).

5. Ligny C. L., De Gelsema W. J. and Beunis M. H. Int. J. appl. Radiat. Isotopes 27, 351 (1976).

6. Bartels P. J., Dekker B. G., Ligny C. L. DE and OldenBURG S. J. Int. J. appl. Radiat. Isotopes 29, 15 (1978).

7. Brand J. A. G. M. van den, Das H. A., Dekker B. G. and LIGNY C. L. DE Int. J. appl. Radiat. Isotopes 30, 185 (1979).

8. Castronovo F. P. J. nucl. Med. 15, 127 (1974).

9. Zimmer A. M. and PAvel. D. G. J. nucl. Med. 18, 1230 (1977).

10. ECKelman W. C. and Richards P. J. nucl. Med. 13, 202 (1972).

11. Gorski B. and KoCH H. J. inorg. Nucl. Chem. 31, 3565 (1969).

12. Owunwanne A., Marinsky J. and Blau M. J. mucl. Med. 18, 1099 (1977).

13. Bratu C., Bratu Ch., Galateanu I. and Roman M. J. radioanalyt. Chem. 26, 5 (1975).

14. Rulfs Ch. L. Crit. Rev, analyt. Chem. 1, 335 (1970). 